\title{
The IWMA, Workers and the Machinery Question (1864-1874)
}

\author{
François Jarrige \\ Translated by Constance Bantman
}

\author{
"Factory nigger, \\ Mine slave, \\ Field vassal, \\ Powerful people, rise up! \\ Worker, seize the machine, \\ Take the land, peasant!" \\ Charles Keller, "Le Droit du travailleur", \\ then "La Jurassienne" [1870].
}

In October 1864, soon after British and French workers declared their wish to create an international labour association with sections in all European countries, temporary statutes and a statement of principles were adopted. In this "inaugural address," written by Karl Marx, several paradoxes stood out from the start: the organized labour movement, in spite of the waves of repression which had followed the failed 1848 revolutions, was being slowly revived, strikes were on the increase and the cooperative movement was spreading. However, "the misery of the working masses has not diminished," even as Europe was experiencing "an unheard of development of industry, and an unheard of expansion of imports and exports". ${ }^{1}$ This paradox - greater wealth

* I would like to thank Fabrice Bensimon, Quentin Deluermoz and Jeanne Moisand for encouraging me to write this text in spite of my initial reluctance, and Michel Cordillot for his close reading and highly valuable feedback.

1 Written by Karl Marx between 21 and 27 October 1864 and published in the booklet Address and Provisional Rules of the Working Men's International Association, Established September 28, 1894, at a Public Meeting held at St. Martin's Hall, in London, in November 1864. A French translation was published in the Journal de l'Association internationale des travailleurs, 
twinned with ever more intense exploitation - made the IWMA necessary, as an international structure meant to restore the balance in the power struggle between capital and labour:

In all countries of Europe it has now become a truth demonstrable to every unprejudiced mind, and only decried by those whose interest it is to hedge other people in a fool's paradise, that no improvement of machinery, no appliance of science to production, no contrivances of communication, no new colonies, no emigration, no opening of markets, no free trade, not all these things put together, will do away with the miseries of the industrious masses; but that, on the present false base, every fresh development of the productive powers of labor must tend to deepen social contrasts and point social antagonisms.

In this founding text, the promise of liberal political economy was rejected as pointless and illusory. In the regime of all-encompassing competition, "improvement of machinery" and "development of the productive powers of labor" could not deliver the dreamed-of emancipation, and in fact they increased inequalities and exploitation. The IWMA, "this child born in the Paris workshops and nursed in London", as the oft-repeated saying goes, came to life in a period of rapid industrial transformations coupled with the labour movement revival, especially in Britain and France, Europe's two leading industrial nations. The London Trades Council was set up in 1860 following the large-scale 1859 building trades strike. In France, while labour disputes remained more discreet, Napoleon III's Second Empire started loosening its grip: a resounding typographers' strike took place in Paris, and that same year, the French authorities allowed crafts to elect their delegates to London's International Exhibition in dependently. In 1862, legislative elections saw the first "working class candidates" and on 25 May 1864, Napoleon II f finally made workers' associations legal.

The IWMA was born in this period of renewed working-class agitation, which was manifested by the publication in France of the "Manifesto of the Sixty", an ambitious programme of demands written in February 1864 by the sculptor Henri Tolain ahead of by-elections, but also in a phase of intense industrialization and economic globalization. The Association was intended

Romance section, 28 January 1866, and reprinted in Jacques Freymond (ed.), La Première internationale. Recueil de documents (Geneva, 1962), vol. 1, p. 6; see Maximilien Rubel, "La Charte de la Première Internationale: Essai sur le 'Marxisme' dans l'Association international des Travailleurs", Le Mouvement Social, 51 (1965), pp. 5, 37. 
as an answer to these challenges, to stimulate practical solidarity and allow worlds of labour to face the profound damages of capitalism. Decisions were made quickly, including against importing blacklegs. There were also sharp debates and controversies regarding work and its transformations. So far, the history of the IWMA has largely been written from an organizational viewpoint; the practical questions with which protagonists were concerned on a daily basis, such as hygiene, work rhythms or mechanization, have received little attention. ${ }^{2}$ And yet these questions were constantly at play in the organization, filling up its congress discussions, shaping interactions between theorists and labour leaders and the worlds of labour which they addressed. The purpose of this article is to shed light on these debates and contacts by exploring the paradoxes which went along with discussions over the machine question within the IWMA. The Association, wavering between social conflicts and wariness towards the new production tools, and the possible futures of a fully mechanized society, was at the heart of the advent of a new industrialist imagination.

\section{The Machine Question and the World of Urban Crafts in the 1860 s}

Throughout the nineteenth century, debates over mechanization, its effects and the conditions for regulating it, took place in labour and socialist movements. The 1850 os and 1860 s in particular witnessed accelerated industrialization: in several crafts, mechanization was discussed in great depth and was a source of concern. Even though local situations were very diverse and varied widely, the workers who joined the International during the 186os sometimes belonged to these industries which were most endangered as a result of industrial transformations. H. Collins underlined this with respect to British workers such as tailors, shoemakers, bootmakers and ribbon makers, who joined the IWMA in droves because "they feared mechanization and were not able to defend themselves". ${ }^{3}$ Marc Vuillemier made the same observations regarding the strategic role of Swiss clockmakers threatened by the progress of mechanized factories, at the expense of small workshops. ${ }^{4}$ While a degree of

2 Even though this stake was certainly mentioned in all overviews of the IWMA's history, see for instance Henryk Katz, The Emancipation of Labor: A History of the First International (Westport, CT, 1992), p. 34, or Mathieu Léonard, L'Emancipation des travailleurs, Une histoire de la Première Internationale (Paris, 2011), p. 114.

3 In La Première Internationale: l'institution, l'implantation, le rayonnement (Paris, 1968), p. 45.

4 While in the more industrial Alemannic Switzerland, the Iwma became implanted only very tentatively, it was above all in the Swiss Jura mountains, where small rural workshops 
caution remains in order on this point, it is beyond doubt that the mutations of capitalism, crystallized notably in the debates over free trade and mechanization, were a foremost concern for the IWMA. By joining this great, inspiring international organization, some protagonists sought support to counteract the threats which their craft faced. While the decision to join the IWMA or not depended on complex motives which remain unexplored, the correlation between an industry's degree of industrialization, the labour market's local situation and the proportion of members seems unquestionable. ${ }^{5}$ The issue of motives therefore remains essential, even though it will probably never be fully elucidated and it would be absurd to reduce it to craft protection, since ideals and desires of emancipation played just as important a part.

The machine question cannot be approached exclusively from congress declarations and theorists' writings - it must also be approached from below, through the answers brought by workers from different industries. While the era of violent insurrections against machines had stopped, there remained sharp conflicts over labour industrialization and its forms; sabotage and various incidents testify to enduring distrust on the part of craft workers and homeworkers towards machines. ${ }^{6}$ And yet, in 1861 , in a text which inaugurated the labour movement revival, its signatories - many of whom were among the founders of the IWMA in France - claimed that "the point is not to destroy machines, these beautiful products of science, but to organize things in such a way that everyone may benefit from them."7 The IWMA was an important stage in the long process whereby the labour movement came to domesticate industrial and technical transformations. While the working class riots of old gave way to different forms of acceptance and arrangements, technical change was increasingly conceived as a source of progress and emancipation. However, concerns remained locally, most often in a diffuse and muted way. Far from surrendering to unanimous enthusiasm, workers expressed widely diverse positions, which were more or less critical. In many crafts - the clothing industry, printing, building - the machine question remained preoccupying. In London, in 1859 and 186o, the introduction of labour-saving technologies

prevailed, that the number of affiliates was the greatest. See Marc Vuillemier, "La Première Internationale en Suisse", in La Première Internationale, pp. 233-234.

5 See Daisy Eveline Devreese, "L'Association Internationale des Travailleurs: bilan de l'historiographie, perspectives de recherches", Cahiers d'histoire de l'Institut de recherches marxistes, 37 (1989), pp. 25-26.

6 See François Jarrige, Au temps des tueuses de bras. Les bris de machines à l'ère industrielle (1780-1860) (Rennes, 2009).

7 L'Organisation des Travailleurs par les corporations nouvelles (Paris [etc.], 1861), p. 6. 
which "to a great extent, rendered the demand for manual labour unnecessary", led to recurring complaints and conflicts, even if the stakes varied considerably from one craft and one region to the next. ${ }^{8}$

In the reports written following their visit to London's 1862 International Exhibition, the French delegates from the various worker corporations frequently echoed these debates. They castigated the effects of machines while fending off accusations that they were hostile to progress and "creative genius." Thus, the woodworkers' delegates criticized "the machines [which], whilst sophisticated, were certainly not without flaws," just like this "new mechanical device invented to cut veneer," which gave "detestable results."9 As for wallpaper printers, they observed that "machines have multiplied extraordinarily in France and abroad."10 Printers also discussed mechanical progress fearfully. In both London and Paris, the mechanization of the printing trade was already well under way, and attempts to make composition automatic continued. But far from celebrating such mechanization, the typography delegates first lauded the progress of "manual screen press printing" which, "being forced to fight against machines", saw its efficiency increase; they regretted that printing had to forsake "the calm and regular paces which it enjoyed in the past, and which made it possible for the worker to rely on a guaranteed task, with profits that could be counted ahead," in order to adopt a "feverish rapidity" which tended to become the norm. ${ }^{11}$ In 1862 , tailors and milliners also observed that workers "have everything running against them: dire poverty, competition, and even machinery. Indeed, sewing machines, which are increasingly widespread, are now creating new obstacles for them! Small employers cannot use them or only get very minor benefits from them, but the large producers gain very substantial advantages from them."12 In their reports, these skilled urban craftsmen called for the right to organize; their ideal was to become independent small employers, forming associations among themselves in an egalitarian republic of crafts.

A few weeks after associations were made legal in France, in May 1864, and even while the IWMA was being set up in London, the Paris bookbinders, led by

8 Cited in Marcel van der Linden, "The Rise and Fall of the First International : An Interpretation", in Frits van Holthoon, Marcel van der Linden (ed.), Internationalism in the Labour Movement: 1830-1940 (Leyden, 1988), p. 330.

9 Délégations ouvrières à l'exposition universelle de Londres en 1862, Rapport des délégués ébénistes, publiée par la commission ouvrière (Paris, 1863), pp. 7, 9.

10 Rapports des délégués imprimeurs en papiers peints, des délégués pour les papiers de couleurs et de fantaisie, publiés par la commission ouvrière (Paris, 1863), p. 6.

11 Rapports des délégués de la Typographie suivi du nouveau Tarif(Paris, 1863), pp. 16, 22.

12 Rapports des délégués tailleurs et des délégués chapeliers (Signé: Leyraud, Besson) (Paris, 1863), p. 29. 
Eugène Varlin, started a fight in June for the working day to be brought down to 10 hours, extra hours to be paid another $25 \%$, and night work abolished. In a memorandum, the strike committee justified these claims by the increase in output resulting from "the extension of machine use."13 The mechanization of work did indeed entail such an increase in offer that "rich people are not enough for orders," "workmen therefore need a pay which is high enough to purchase, and the time which is needed to own." Faced with the risk of overproduction, workmen mobilized to increase salaries and cut the workday - the only way to soften the devastating effects of mechanization. The bookbinders' strike was a success at first, and employers were forced to give in in late September as orders piled up; Varlin came out of the struggle with real prestige and found himself placed under police surveillance.

Sewing machines also triggered endless debates throughout the 186os. Thus, in 1866, the Manchester tailors asked for working hours to be cut, and rates to be increased in order to cope with their growing use in the clothing industry. ${ }^{14}$ In the shoe industry, the introduction of sewing machines had already caused a sustained conflict in Northampton in $1858 .{ }^{15}$ After visiting the Singer factory in the Us, a manufacturer had secretly introduced one during the winter of 1857, resulting in the setting up of an "anti-machine committee" in charge of organising the strike. Shoemakers then committed to "resisting through all legitimate means the introduction of machinery in shoe and boot factories" across Northamptonshire. In 1858, they set up a mutual aid society and entered negotiations with the manufacturers. ${ }^{16}$ The dispute dragged on for months but the workers were eventually forced to give in and accept to work at the machines, in exchange for a pay rise. As early as $1865,1,500$ sewing machines were in operation in Northampton and the trade unions' initial opposition had evolved into negotiated cooperation. ${ }^{17}$

In France, where the penetration of sewing machines was slower, the shoemakers' delegates to the 1867 Exhibition also denounced "machine overuse"; they criticize the coarseness and heaviness of products made by the

13 Michel Cordillot, Eugène Varlin, chronique d'un espoir assassiné (Paris, 1991), p. 32.

14 Le Conseil Général de la Première Internationale, 1866-1868 (Moscow, 1973), p. 32.

15 R.A. Church, "Labour supply and innovation 1800-1860: The Boot and Shoe Industry", Business History, $12 / 1$ (January 1970), pp. 25-45, pp. 32-35.

16 Church, "Labour supply and innovation $1800-1860$ " p. 36.

17 On the topic of the shoemakers' work industrialization after 1850, see Alain Cottereau's comparative study, "Problèmes de conceptualisation comparative de l'industrialisation: l'exemple des ouvriers de la chaussure en France et en Grande-Bretagne", in Suzanne Magri and Christian Topalov (eds.), Villes ouvrières, 1900-1950, (Paris, 1990), pp. 41-80. 
machines. ${ }^{18}$ In the delegates' reports just as in the debates of the 1867 workers' commission, which brought together the delegates elected by the 118 Parisian trades in order to represent them at London's Universal Exhibition, the issue of machinery was discussed frequently. As shown by Michel Cordillot, the debates within this commission were "of a high standard," and largely reflected the "concerns of Paris's labour aristocracy in the face of the structural changes $[\ldots]$ which they dreaded as so many threats." ${ }^{\prime 19}$

\section{Watchmakers and Weavers Facing Mechanical Production}

Quite far from these elite urban workers, other workers' groups - some of which played an important part in the early days of the IWMA - were confronted with mechanization in the late 186os. In the Swiss Jura's mountains as in some textile-producing regions, workers and small employers often regarded innovations as "suspicious" and "dangerous". The IWMA's implantation took place just as the debates over machinery were raging. In Switzerland, notably, steam machines were first adopted with great caution in fitters' workshops, since their high cost, dangerousness, and their great consumption of wood and water made them look suspect. ${ }^{20}$ Watchmaking had developed in the nineteenth century as a reaction to demographic growth and a complement to agricultural work and cattle farming. In these tough mountains, the spread-out workshops in the context of the domestic system known as établissage hosted skilled workers making a high-value product in an environment which was usually family-based. ${ }^{21}$ But during the 186 os this system encountered growing difficulties due to the competition from goods produced at a low cost in the United States' large mechanized factories. Such a crisis and questioning of the domestic system of industry, where men worked scattered

18 Cited by Cottereau, "Problèmes de conceptualisation comparative de l'industrialisation", pp. 41-80.

19 Michel Cordillot, "La commission ouvrière de 1867 ", in Aux origines du socialisme moderne (Paris, 2010), p. 61.

20 Jean-Marc Barrelet, "Les résistances à l'innovation dans l'industrie horlogère des montagnes neuchâteloises à la fin du XIXe siècle", in Innovations technologiques et civilisation (XIXe-XXe siècles) (Paris, 1989), pp. 215-228; François Jéquier, "Le patronat horloger suisse face aux nouvelles technologies (XIXe-Xxe siècles)", Bulletin du centre d'histoire économique et sociale de la région lyonnaise, 1 (1977), pp. 23-69.

21 See Marianne Enckell, La Fédération jurassienne: Les origines de l'anarchisme en Suisse (Lausanne, 1971) ; and in particular Mario Vuilleumier, Horlogers de l'anarchisme. Emergence d'un mouvement : la Fédération jurassienne (Lausanne, 1988), pp. 281-282. 
in various sites, made workers and small employers hostile. The first Jura-based sections of the IWMA actually took up this viewpoint and the watchmakers prided themselves on the fact that "manufactures have not yet been organized here," whilst calling for an "energetic" fight against the use of machinery and mechanized manufacture which threatened their autonomy and lifestyle. ${ }^{22}$ These watchmakers were not hostile to technology as a rule - they themselves had brought in considerable innovations and introduced several mechanized tools in order to perfect home production, but these innovations - which often remained secret - aimed primarily to reinforce etablissage by perfecting the work of scattered domestic workers rather than by bringing them all together in large concentrated factories more quickly. The fight against mechanized methods was first a fight for the preservation of home production as opposed to encasement within a factory, which the workers saw as an attack upon their family lives and freedom. Joining the IWMA was meant to offer additional resources in this fight.

In the textile industry, which had been really caught up in the violent struggles against machinery in the first half of the nineteenth century, the denunciation of technical change - charged with speeding up the pace of work and putting pressure on wages - also persisted, as mechanization intensified, under the impact of international competition. Jacques Rougerie insisted on this "obvious" fact - that, outside Paris, Marseilles and Lyons, it was "essentially in textile regions that the [International] Association" had taken root in France. ${ }^{23}$ Whether it was the surroundings of Rouen, Reims, Troyes, the North (Roubaix), or the East (Mulhouse), it was in these territories shaped by textile work that the IWMA became established, and especially the oldest ones, where scattered work persisted and mechanization slowly took shape. ${ }^{24}$

Thus, in the Roubaix area, the first major wave of mechanization started between 1856 and 1866 . While the 1860 Anglo-French Free Trade treaty increased competition and led producers to embrace mechanization, the equipment was quickly transformed: in spinning, the number of self-acting mule overtook "traditional looms" while in weaving "mechanical looms" supplanted home-based technology. ${ }^{25}$ As early as May 1858 , some weavers had launched

22 Enquête ouvrière faite par l'Association internationale des Travailleurs, Section de Sonvilliers, in La voix de l'Avenir, n. 7, (8, 17, and 24 February 1867), cited by Vuillemier, Horlogers de l'anarchisme, p. 283.

23 Jacques Rougerie, "Les Sections françaises de l'Association internationale des travailleurs", in La Première Internationale, p. 113.

24 For a precise and still very helpful table of the sector's mutations at the time, see Claude Fohlen, L'Industrie textile au temps du Second Empire (Paris, 1956).

25 Archives Départementales du Nord, M581-160: état dressé par le Commissaire de police de Roubaix en septembre 1862. 
a petition asking for steam powered weaving looms to be banned. Within a few weeks, several hundreds of signatures were collected and brought to the Legislative authority. But the deputies of Northern France succeeded in defeating the initiative, arguing that "the onward march of French industry must be maintained at least at the same level as that of neighbouring powers". ${ }^{26}$ Whereas rural weavers tried to protect their way of life and autonomy by accepting wage cuts rather than enrolling into the new mechanized factories, textile sector employers imported Belgian migrants to populate the new factories and work with the machinery. In order to further increase yields, in parallel, industrialists sought to increase discipline and fines and to force the workforce to keep several jobs at the same time - a widespread practice in England. Faced with such hardened conditions, the Roubaix workers stopped work in March 1867; during a spectacular riot which made a strong impression on public opinion, they destroyed the machinery and wrecked the factories. ${ }^{27}$ A few weeks after that stoppage, a small local section of the IWMA was set up in Roubaix, structured around Charles Lécluse. ${ }^{28}$

The riot in Roubaix, which happened just after the Paris bronze metal worker strike, was part of a wave of strikes, supported by the IWMA, and triggered many debates within the organization. The direction of the Paris section of the International declared its solidarity with the Roubaix workers, while firmly disapproving violent acts and destructions. A press statement was published on 24 March to publicize the support of the IWMA to the strikers and - modest financial help was quickly collected in Paris, Lyons and Rouen. In its address to the "Roubaix workers", the Paris correspondents invited all IWMA members to "bring [their] material and moral support" to the strikers, these "suffering brothers," whose "fair grievances" must be taken into account. But at the same time, they disapproved of violence and put forward an interpretation which depicted the conflict and its violent acts centred on a rejection of technical progress as archaic: "Whatever your fair grievances may be, nothing can justify the acts of destruction of which you have made yourselves guilty. Just think that machinery, which is a work tool, must be sacred for you, just think that such violent acts jeopardize your cause and that of all workers. Just think that you have just provided the opponents of freedom and the slanderers

26 Firmin Lentacker, “Un épisode de la Révolution Industrielle: Ouvriers à demeure, ouvriers immigrés dans l'industrie cotonnière de Roubaix de 1857 à 1864", Revue du Nord, 69/ 275, (oct. - dec. 1987), pp. $767-775$.

27 Archives Nationales, F12 4652: rapports de Préfet du Nord, mars 1867; regarding this strike, see F. L'Huillier, La Lutte ouvrière à la fin du Second Empire (Paris, 1957), p. 177.

28 See Cordillot, "La section française de l'Internationale et les grèves de 1867" in Aux origines du socialisme moderne, pp. 33-56. 
of the people with weapons," they wrote. ${ }^{29}$ For the French IWMA representatives, such violent acts were proof of the lack of education and the oppression weighing upon workers, and only the spread of "economic education through conferences, meetings, pamphlets, papers" could put an end to it.

\section{The IWMA and the Debate about Machinery}

Even if the adoption of machinery was far from being the only cause for conflicts at the time and if the struggles caused by mechanization gradually vanished, the machine question continued to trigger complaints and protests. It provided the background of many struggles over wages or the length of the workday, all the more as conditions became even harder in1867. It was therefore expected for the IWMA to take a formal stance over these questions by offering answers likely to qualify the destruction which went along with "the advance of production forces."

When it appeared in the 1860s, the IWMA inherited the debates which had already taken place among the first socialist generations. In the 1840s, when conflicts erupted sporadically, socialist adopted positions towards machinery which were often ambiguous: they castigated their devastating effects whilst suggesting domesticating their future use for the benefit of proletarians. ${ }^{30}$ Proudhon, for instance, bemoaned the effects of technical change which is degrading for workers "by downgrading him from the status of an 'artisan' to that of a labourer". ${ }^{31}$ Far from being enthused by machinery, he emphasized its "antinomies" and ambiguities: "Machines promised us an increase of wealth; they have kept their word, but at the same time endowing us with an increase of poverty. They promised us liberty; I am going to prove that they have brought us slavery" by instituting the wage system. Indeed, for Proudhon, "wages issued in a direct line from the employment of machinery". At the same time, however, Proudhon asserted the optimistic vision of the increase of general

29 Le Courrier français (24 March 1867), p. 5 cited by Cordillot, "La section française de l'Internationale et les grèves de 1867", p. 44; La Liberté (24 March 1867), signed by Tolain, Varlin, cited by Michelle Perrot, Les Ouvriers en grève, (1871-189o), 2 vols., (Paris [etc.], 1974). See also L'Huillier, La Lutte ouvrière à la fin du Second Empire, p. 17 ; and Cordillot, "La section française de l'Internationale et les grèves de 1867", p. 44.

30 Regarding socialist debates and analyses of machinery in the first half of the nineteenth century, see François Jarrige (ed.), Dompter Prométhée. Technologie et socialismes à l'âge romantique (Besançon, 2016.).

31 Pierre Hauptmann, Pierre-Joseph Proudhon: sa vie et sa pensée, 1809-1849 (Paris, 1982), Part 1, p. 773 . 
welfare which should eventually be expected from it. For him, machines were actually "the symbol of human liberty, the sign of our domination over nature, the attribute of our power, the expression of our right, the emblem of our personality." ${ }^{2}$ Already in the 1840 s, Marx had rejected these concerns and stated the benefits of machinery, which was to give birth to the proletariat and the future communist society free from competition.

In the first IWMA congresses, the machine question still triggered recurring debates, which testified to ideological and political fault lines splitting the organization in its early years of life. It was in 1866 that the first actual IWMA congress was organized, in Geneva: debates were then dominated by the French delegation heavily influenced by Proudhonism, distrust towards strikes and the call for "mutualism", even if, as early as the 1867 Lausanne congress, this "Proudhonian" influence seemed to recede. At the Brussels congress running from 6 to 13 September 1868, the "collectivists" prevailed, the legitimacy and necessity of strikes were asserted and the call for collectivism carried the day, even if such divides are slightly reductionist and do not fully account for the diverse positions being expressed. ${ }^{33}$ In each of these early congresses, the machine question repeatedly came to the fore. ${ }^{34}$ Thus "machines and their effects" were debated at the 1866 Geneva congress, along with discussions about the reduction of working hours, the division of labour and the extinction of the wage system. The following year, during the Lausanne congress, the Frenchman François Chemalé read a report focusing on "the impact of sewing machines on the lives of female labourers". ${ }^{35}$ But overall, regarding these issues, the "Congress merely restated the declaration voted the previous year in Geneva."

It was during the third congress, organized in Brussels in 1868, in the wake of the Roubaix insurrection, that the machine question was debated most overtly and in greatest detail. This decisive congress took place from 6 to 13 September 1868, and brought together delegates from Belgium, France, the United Kingdom, Germany, Italy, Switzerland and Spain. The programme included eight questions, the second of which dealt specifically with the "impact of machines on the wages and situation of workers." It had initially been raised with the IWMA General Council in London in January 1868, and had then been placed

32 Pierre-Joseph Proudhon, System of economical contradictions: or, The Philosophy of Poverty (Paris, 1846), Chap. Iv : "Of Machinery", transl. by Benjamin Tucker (1888). Available at https://www.marxists.org/reference/subject/economics/proudhon/philosophy/.

Annie Kriegel, “L'Association internationale des travailleurs (1864-1876)", in Jacques Droz (ed.), Histoire Générale du socialisme (Paris, 1997 [1972]), vol. 1, p. 616.

34 James Guillaume, L'Internationale, documents et souvenirs (1905), vol. 1.

35 Oscar Testut, L'Internationale, ses origines, son but, son caractère, ses principes, ses tendances, son organisation, ses moyens d'action, ses ressources, son rôle (Paris, 1871), p. 131. 
on the agenda of the Brussels congress. Marx initiated the General Council's proceedings with a study of the "consequences of using machinery under capitalism". ${ }^{36}$ During the meetings on 28 July and 4 August, he returned to the ideas which he had developed in the first volume of Capital, which had been published in German the previous year. A resolution was eventually adopted on 11 August. Georg Eccarius, who was close to Marx at the time, was in charge of presenting it to the congress during the 9 September 1868 session.

The Marxian analysis of machinery has generated much writing and led to occasionally contradictory interpretations; in fact, Marx's analyses regarding the long-term dynamics of capitalism must be distinguished from his ideas about the immediate effects of machinery for workers. In the very short term, Marx acknowledged, machinery caused many tragedies and increased the proletarians' destitution. The introduction of automated weaving looms, for instance, led to the disappearance of the former manual textile workers, in England just as in India, where rural workers were "destroyed" by the cotton fabrics now mass produced in Manchester's mechanized factories. ${ }^{37}$ However, in spite of such temporary distress, Marx concluded that in the end, machinery fostered the advance of productive forces, accelerated class antagonisms and the capitalist system's contradiction, and therefore prepared the latter's overthrow and its replacement with "a new society."

Marx's text was widely circulated in the wake of the congress; the IWMA served as a diffusion channel for the analyses which he had put forward the

36 Karl Marx, "On the consequences of using Machinery under Capitalism" (28 July 1868), in Marx and Engels Collected Works (MECW), (1985), vol. 21, p. 382, available online: https://marxists.Org/archive/marx/iwma/documents/1868/machinery-speech. htm. The context in which Marx's speech was first published can be found in the transcript of the General Council's session published in The Bee-Hive on 1st August 1868, and in a pamphlet published in London the following year: The IWMA. Resolutions of the Congress of Geneva, 1868, and The Congress of Brussels, 1868 (London, 1869). A French version also appeared in several papers: Le Peuple belge (11 September); La Liberté (13 September); La Cigale (20 September); La Tribune du Peuple (8 November 1868); and L'Egalité (24 April 1869); in German, the resolution appeared in the Demokratisches Wochenblatt dated 19 September 1868 and in the Arbeiter Zeitung (New York) dated 16 August 1873, and it was also published in Spanish and Italian. Recently this text and the most valuable documents of all the currents of the IWMA have been published in English: Marcello Musto (ed.), Workers Unite! The International 15o years later (London [etc.], 2014).

37 Karl Marx, Capital (vol. 1), Chapter 15: "Machinery and Modern Industry". Available online at https://www.marxists.org/archive/marx/works/1867-c1/ch15.htm.

38 Ibid; see Paul S. Adler, "Marx, Machines, and Skill", Technology and Culture, 31, 4 (Oct. 1990), pp. $780-812$. 
previous year in Capital, especially in Chapter 15, which is entitled "Machinery and Modern Industry". It was actually in relation to the topic of machinery that the first allusion to Capital appeared in the IWMA debates. During the discussions which took place in Brussels on 9 September 1868, Lessner, a German tailor in exile in London, read extracts from Marx's work, "in which this question is extensively dealt with", he claimed. ${ }^{39}$ During that congress session, Steens, reporting on behalf of the "machinery committee," read out three reports written by the sections from Brussels, Liège and the Paris bookbinders. Lessner, Coulon, Pellering, Eccarius, Cohn, Scheppler, Hins, Steens, Tolain, de Paepe, Murat, Tartaret, Theisz and Brismée took part in the debate about the impact of machinery and more specifically the usefulness of mutual help societies to face them. ${ }^{40}$ The congress concluded that machinery, like all other work tools, should belong to the workers themselves and be used for their benefit.

During the debates, various speakers took up Marx's analysis, distinguishing between short- and long-term effects and discussing strategies to regulate ongoing transformations. The report presented by the Brussels sections thus stated directly that "the social wound is spreading as a direct result of inventions and discoveries." Unlike employers who relied on machinery to increase their profits, the report explained, "the workers, appalled to see steam supplant human strength, and machines obliterate millions of workers, had nothing but loathing for the hellish genius of the worsening of their destitution in present society, and the destruction of these tools of death and exploitation." The Liège section's report also asserted that "in contemporary society, the introduction of machinery is detrimental to most, and propitious to the exploitation of workers". ${ }^{41}$

And yet, during the debates, the workmen's delegates gradually came round to the views upheld by socialist thinkers for a few decades - starting with Marx regarding the neutrality of techniques and the benefits to be expected from them in the socialist society of the future. They distinguished between the phase of introducing machinery, that of transition and their "role in the future." The IWMA's goal was to create "a society made of federal and solidary associations", where capital would no longer be a source of exploitation but "accumulated work"; in this ideal society, machines would no longer engender misery, but

39 "Freymond, La Première Internationale. Recueils de documents, p. 297".

40 Among the many published accounts from these debates, see Oscar Testut, Association Internationale des Travailleurs (Lyon, 1870), p. 155; or Freymond, La Première Internationale. Recueil de documents, pp. 291-300.

41 Freymond, La Première Internationale. Recueils de documents, pp. 291-292, 295. 
rather "increase everyone's wellbeing." Instead of "cursing machinery," the delegates repeatedly asserted, workers should carry their "hatred and anger" "higher," attacking "the social anarchy" entailed by capitalism. ${ }^{42}$ This was the statement of a theory which was to prove quite influential: techniques are neutral, it is their misuse in the context of the capitalist system which makes them dangerous. While a consensus regarding the long-term beneficial impact to be gained from machines seemed to emerge, there was nevertheless a debate between the French Tolain and the Belgian De Paepe regarding the immediate course of action to be adopted. Whereas the former considered that no resolution needed to be taken regarding the machinery question, since it was "the current system" in its entirety which should be transformed, the latter, in contrast, insisted that intervention was necessary: "here, the cold logic of the political man can no longer satisfy the worker. They talk to him pointlessly about progress, usefulness for the future, he sees that machinery is pushing him out of the workshop, and he will long be dead before machines bring about any progress in his brethren's condition. Workers will therefore decide to fight against the so-called rule of machinery, just as he fights against the law of offer and demand through strikes." ${ }^{3}$

De Paepe rejected Tolain's solution, as the latter seemed to advocate "abstention" and called for active resistance: "in the current situation, there is cause, for workers organized into mutual aid societies, to intervene in the introduction of machinery in the workshops, so that this introduction may only happen with some guarantees or compensation," that is to say by imposing clauses pertaining to qualifications, the duration of work, the identity of the workforce in charge of working these machines. In the discussion which followed this proposition, the Belgian Brismée actually noted how effective "the opposition from mutual aid societies to new inventions" proved, and cited the example of "mechanical typesetting which in practice, it had never been possible to introduce."44 The French François Murat also supported this proposal, pointing to the previous year's violent strike in Roubaix, somewhat hastily depicted as "resulting from the introduction of new machinery": the upheaval would

42 Freymond, La Première Internationale. Recueils de documents, p. 295.

43 Freymond, La Première Internationale. Recueils de documents, p. 298: about the Belgian De Paepe, a keen reader of the socialists, a typographer-corrector who worked in various Brussels printing works and set up the local IWMA section in 1865, see Entre Marx et Bakounine, César De Paepe: correspondance presentée et annotée par B. Dandois (Paris, 1974).

44 Ibid., p. 30o; regarding this machine and the constant debates which went along with its development, see Francois Jarrige, "Le mauvais genre de la machine. Les ouvriers du livre et la composition mécanique en France et en Angleterre (1840-1880)", Revue d'histoire moderne et contemporaine, 54-1 (Jan.-March 2007), pp. 193-222. 
have been avoided if the workers had been organized in powerful mutual aid societies able to negotiate and regulate the introduction of new methods. The machine controversy eventually led to an analysis of strikes and working-class strategies of action. The delegates, finding it impossible to agree on a shared resolution, concluded with a moderate position: "let us conclude that at least in theory machines ought to be belong exclusively to the workers." ${ }^{45}$ In the end, the congress came to an uncertain conclusion which was an attempt to synthetize the different positions: "Concerning machines, the Congress declares that they must belong to workers and work for their benefit, that it is through association and mutual aid that the producer must come to own them himself. But that there is cause, from this instant, to intervene into the introduction of machines in workshops so that this gradual transformation of tools may only be effected along with serious guarantees or fair compensation for workers." 46

\section{The IwMA and the Waning of the Machinery Problem}

As the Brussels congress drew to a close, the machinery problem had therefore been solved in appearance by being postponed, adjourned to the future collectivization of the means of production and local negotiations among workers organized into mutual aid societies and employers. Thanks to the association, the union of workers and the multiplication of cooperatives, the IWMA finally mobilized the machine question to justify its existence. In the face of the morbid effects of mechanization in the system of general competition generated by the promotion of free trade, only the alliance of workers across nations could actually offer a solution. The machine question, thus solved, quickly disappeared very widely from the debates of the IWMA.

The fourth congress, which took place in Basel in September 1869, no longer discussed that question. Even as that congress enshrined the growing power of the organization and its commitment to support workers' struggles, from then on the debate was dominated by the questions of inheritance and landed property, a resolution in favour of "collective ownership" of the land was actually adopted by the majority in spite of opposition from a few French Proudhonians who feared that the IWMA might scare off agricultural workers as a consequence. During these discussions the machine question only remained in the background, the woodworker and former Chartist Benjamin Lucraft asked

\footnotetext{
45 Freymond, La Première Internationale. Recueils de documents, p. 340.

46 According to the resolution voted by the congress - see Guillaume, L'Internationale, documents et souvenirs, p. 179 .
} 
for instance for "the land to become the property of the state" and for "the working class to seize political power" and "turn Parliament into a workingclass Parliament." Following the old Chartist logic, in this technocratic state, instead of being left to the peasants' obscurantism, "farming of this land [would be] led by Parliament, by the nation's Council, and intelligent men would apply themselves to perfecting agricultural machinery." But these views were strongly opposed by the journalist Amédée Langlois, Proudhon's friend and executor, who denounced such a technocratic and authoritarian conception of the state, "bullying into work, enlisting workers in squads, under the command of engineers, foremen, instituting a strong hierarchy."47 The machine debate was increasingly swallowed up into the controversy between the champions of collectivization and "anti-authoritarian" socialists, it was gradually subsumed by the tensions opposing the advocates of political action and those emphasizing workers' autonomy, those wanting a collectivization of the means of production and, control by the state and those calling for them to be appropriated by workers. It was no longer productive machinery and industrial techniques which were discussed, but rather the political machinery of the state, perceived with growing defiance by the anti-authoritarian or federalist branches forming at the time.

Besides, other, more urgent stakes came to the fore in the early 1870s: the Franco-Prussian war, the Paris Commune, extending beyond European borders, the national question, repression and exile - all of this led workers in the process of organizing to turn their backs on a struggle which seemed doomed to fail. Instead of challenging mechanization, it was preferable to use political ways and press for collectivization. The fifth congress scheduled to take place in Paris in September could not be held; the period was busy with scissions, divisions and personal feuds. As the conflict between Marx and Bakunin escalated, the IWMA's Romand federation split up, the Jurassian sections seceded during the April 1870 congress in La Chaux de Fonds. During the September 1872 Hague congress, the delegates ended up voting in favour of expelling Bakunin and his supporters. A week later, the latter reacted by congregating in Saint-Imier, in Switzerland, in order to enshrine the break and create an "antiauthoritarian" International. In parallel, the IWMA extended to new territories, with sections being set up in Portugal, Spain, Romania, Denmark, but also Northern America. In these young or rural countries, industrialization was barely getting under way and triggered fewer complaints over mechanization,

47 See Compte-rendu du Ive congrès international: tenu à Bâle, en septembre 1869 (Brussels, 1869); Freymond, La Première internationale, recueil de documents, vol. II, pp. 3-131; Léonard, L'Emancipation des travailleurs, p. 159. 
even if the situation in Catalonia would deserve closer scrutiny. In the United States, the chaotic way in which the economy picked up following the Civil War contributed to making work abundant and the machinery question a relatively secondary issue.

After 1871, only the Swiss watchmakers seemed to remain opposed to machinery and factories. But the Jura Federation affiliates were now pressing for workers to accept a process which seemed unavoidable. Thus, they proclaimed that "workers' associations are powerless when it comes to preventing the introduction of machinery in industry; they may delay it a little, and that's all; sooner or later the association of capital comes to prevail upon the workers' resistance and the rule of machinery is established." ${ }^{\prime 8}$ Since the late 1860 s, the rule of machinery had indeed settled in Switzerland: in 1871, a new mechanical watch factory was set up in the region of Le Locle; the industry's crisis became more acute after 1874, American watches made in huge mechanized factories with hundreds of workers now flooded markets previously controlled by the Jura workers. ${ }^{49}$ In this context, the fight remained bitter and, in 1873 , several workshops were blacklisted again by Swiss workers: this happened in La Chaux de Fonds and Geneva, where "several workshops ... were blacklisted due to the use of machinery." ${ }^{\prime 5}$ But far from being supportive of these disputes, the Jura Federation affiliates opposed them with mounting vigour. As employers started introducing machines in order to try and compete with the Americans, IWMA militants sought ways of solving the machine issue while avoiding strikes. Even though these disputes in order "to preserve current working conditions" and this "war from workers against machinery" were legitimate, and although fitters were, without a context, allowed to pursue this course of action, their strategy now appeared as a dead end.

It was neither "out of ignorance nor out of hatred for industrial progress" that workers now opposed mechanization, but because of "the ill effects arising from machinery and the division of labour." The stake was therefore to reduce these ill effects whilst retaining the benefits of mechanized production. However, there was only one way to achieve this goal: "Machines, and all work equipment in general, must no longer be the employers' property, but become

48 Bulletin de la Fédération jurassienne de l'Association internationale des travailleurs, 14 (13 July 1873), p. 2.

49 Whereas in 1872 , Swiss watchmaking still exported 366,000 watches to the United States, the figure collapsed to 65,000 just as American production soared. See Vuillemier, Horlogers de l'anarchisme, p. 285.

50 "Congrès des monteurs de boîtes (dimanche 22 juin 1873)", Bulletin de la Fédération jurassienne de l'Association internationale des travailleurs, 14 (13 July 1873), p. 1. 
the workers' collective property." Consequently, "the true aim of workers" societies must be, not to oppose machinery, but to become the owners of machinery and all tools themselves. And this is the only way of ensuring that our modern society does not end up reconstituting a caste of slaves which would be a thousand times more wretched than Roman Empire slaves and America's niggers.' ${ }^{11}$ In the end, Jura Federation members opposed defensive strikes, which were rejected as being ineffective; they analyzed mechanization by adopting the new collectivist rhetoric which had come to prevail within the IWMA. But while the "Marxists" increasingly emphasized the role of the State as an agent for this collectivization, Jura Federation militants defended their local appropriation by workers' associations.

Between its beginnings and its gradual dismantlement in the mid-1870s, the IWMA discussed mechanization and its effects in great detail. But while before 1870 it was a very heated and recurring debate, it waned after that date, pushed to the background by the pressing matters of the day. The definition which gradually came to dominate portrayed machines as a set of neutral tools and instruments, which, in capitalist hands, were sources of oppression, but indispensable means of emancipation for the future. Since techniques were neutral, first and foremost, it was their modes of appropriation which ought to be discussed; the stake was not to blame the new industrial trajectory anymore, but to have it benefit workers through the intervention of production cooperatives or the state. The consideration of the machine question sheds light on both the trajectory and stakes of the IWMA, it followed its first steps, shaped interactions between the organization's top tier and grassroots, between delegate workers and the crafts in all their diversity. It determined the hopes of workers who saw the organization as the tool which they needed to regulate and soften threatening transformations. Therefore, the IWMA was at once a remarkable device to fight inequalities and resist industrial capitalism, and one of the venues where the use of machines in the worlds of labour was gradually accepted. For reasons which differed from those of employers, the IWMA was won over to the promises of mechanization, which it saw - as Marx did - as a tool of emancipation and the prerequisite of equality in affluence.

51 Bulletin de la Fédération jurassienne de l'Association internationale des travailleurs, 14 (13 July 1873), p. 2. 